\title{
Editorial
}

\section{Housing and Health: Here We Go Again}

\author{
Lorenzo Capasso ${ }^{1, *(1)}$ and Daniela D'Alessandro ${ }^{2}$ (1) \\ 1 Italian Ministry of Education, USR Abruzzo (Regional Office of Abruzzi), 66100 Chieti, Italy \\ 2 Department of Civil Building and Environmental Engineering, "Sapienza" University of Rome, \\ 00100 Rome, Italy; daniela.dalessandro@uniroma1.it \\ * Correspondence: lorenzo.capasso@posta.istruzione.it
}

check for

updates

Citation: Capasso, L.; D'Alessandro, D. Housing and Health: Here We Go Again. Int. J. Environ. Res. Public Health 2021, 18, 12060. https:/ / doi.org/10.3390/ijerph182212060

Received: 8 November 2021

Accepted: 15 November 2021

Published: 17 November 2021

Publisher's Note: MDPI stays neutral with regard to jurisdictional claims in published maps and institutional affiliations.

Copyright: (C) 2021 by the authors Licensee MDPI, Basel, Switzerland. This article is an open access article distributed under the terms and conditions of the Creative Commons Attribution (CC BY) license (https:// creativecommons.org/licenses/by/ $4.0 /)$.

\begin{abstract}
Housing is one of the major determinants of human health and the current COVID-19 pandemic has highlighted its relevance. The authors summarize the main issues, including dimensional standards, indoor air quality, safety, accessibility, neighborhoods, and area characteristics. The authors propose an operating scheme in order to implement actions to improve residential wellbeing on a local, national, and international level.
\end{abstract}

Keywords: housing and health; built environment; indoor health; public health

\section{Introduction}

Our readers might wonder, why another special issue on housing and health? Is it really necessary to study and work on the relationships between housing and human health? Is it still a relevant issue in today's world? We are quite sure that the answer is yes, because housing was, is, and will remain a central theme for public health worldwide. We must strengthen our knowledge to ensure the best and healthiest living condition for the entire world population. We therefore strongly need new research on this topic, not just to evaluate the current situation in different countries and contexts, but also to be able to validate new solutions aimed at improving the health standards of housing and making them suitable and affordable for a larger portion of the human population.

\section{Relevance of Housing for Human Health}

Housing represents a core and traditional topic of public health [1], despite having been wrongly considered an "old" topic not worthy of attention by many public health researchers and practitioners in different countries [2]. International studies widely and strongly recognize the indoor environment as a major health determinant [1,3-6], in both developing and developed countries [7-9]. In the most economically developed countries, nowadays, people spend up to $90 \%$ of their lifetime indoors $[6,10,11]$, while in developing countries, considerable levels of indoor pollution make housing unsafe, with a remarkable impact on the health of inhabitants $[9,12,13]$. The occurrence and re-occurrence of pathologies related to the quality of built environments, exacerbated by the severe current socio-economic crisis, upholds once more the ultimate importance of the domestic environment as a principal living space $[6,9,11,13,14]$. The current pandemic conditions have exacerbated housing, social, and sanitary problems, highlighting different needs in different countries and contexts $[15,16]$. Several issues characterize dwellings' impact on human health, but considering demographical, socioeconomic, and epidemiological factors, we might summarize the main housing issues, that in our opinion ought to be explored, as these key problems:

- Dimensional standards

- Indoor air quality

- Safety

- Accessibility 
- Neighborhoods and area characteristics

Relevant classical issues such as thermal and hygrometric comfort, lighting, noise protection, water supply, and waste disposal have a strong impact on both psychological and physical health of inhabitants. Despite being widely recognized as key factors for healthy living environments at both scientific and legislative levels, these factors are not adequately guaranteed in all dwellings worldwide [5,6,17-19]. New emerging threats and opportunities for indoor health have emerged in recent years and must be investigated, among which are surely electromagnetic fields and privacy, linked to new technologies and domotics [20-30].

\section{Dimensional Standards}

Sufficient dimensional area is a key determinant for healthy housing [31]. According to the World Health Organization (WHO), in terms of living space, dwellings must be large enough to comfortably accommodate people of different ages and must guarantee sufficient space to fulfill the safety and privacy needs of the occupants [32,33]. Dwellings nowadays ought not only to meet a basic human need for shelter, but also contribute to the physical and psychological well-being and social integration of the residents [33,34]. Housing with substandard spacing is linked with mental and infectious diseases $[4,6,33,35]$. The strong correlation between the built environment, overcrowding, and the spread of infectious diseases is well documented in particular for some pathologies such as tuberculosis and epidemic cerebrospinal meningitis, and is now coming back as a fundamental threat due to the COVID-19 pandemic [6,33,36-41]. Insufficient housing space conditions and the lack of privacy can be related to psychiatric conditions such as anxiety and depression $[32,42,43]$. At the same time, it represents an issue for people with physical disabilities, particularly if they require mechanical supports $[17,32]$. Space shaping can also influence social interaction and integration, determining how much interaction occurs and its results $[19,32,33]$. Defining the appropriate amount of internal space for a dwelling is a complex issue and there is not a vast amount of evidence-based data on space standards. It is not only related to floor area, but also to several different parameters that can influence air circulation and space perception, among which are ceiling heights, walls colors, rooms proportions (length, depth, diagonals), windows size, and natural lightening [6,44-46].

\section{Indoor Air Quality}

Indoor air is an historical and widely recognized health determinant [3-7,47-50]. The first identified pollutant was carbon dioxide, discovered by Pettenkofer in the second part of the 19th century [51]. Subsequently, the number of new pollutants has been widened, and many actions have been taken to improve indoor air quality [7,50-54]. Lowquality indoor air is recognized as a risk factor for chronic and acute diseases such as neoplasms, asthma, respiratory infections, eczema, and rhinitis [55-62]. Important public health goals were achieved by ameliorating building ventilation $[6,7,39,51,53,63-69]$ and tackling tobacco smoke, radon, formaldehyde, and other volatile organic compounds (VOCs) $[6,7,66,67,70-75]$. The identification of sick building syndrome, building-related illnesses, and multiple chemical sensitivity provided an important base for further indoor air improvements [76-81]. A cause of concern, at least in the most economically developed countries, is the decrease of air exchange rates related to energy saving technologies and policies, which may generate a future deterioration of indoor air quality [82-84] In developing countries, indoor air quality is often still extremely poor, and a major health threat is represented by the combustion of solid fuels and, in general, by household cooking and space heating $[8,12,85,86]$.

\section{Safety}

Despite a lack of reliable epidemiological data on a global basis, home accidents are among the leading causes of death, infirmity, and disability worldwide, in both developing and developed countries [87-89]. The most common accidents include falls, poisoning, 
fire and burning, choking and suffocation, drowning, and submersion [90,91]. Particularly fragile categories are children and the elderly [86,92-95]; among the elderly, accidental falls cause worldwide large mortality and even larger morbidity and disability [95,96], representing a rising public health issue because of the population aging [97-101].

Among emerging safety issues, we would also include structural problems related to extreme natural phenomena, such as floods, tsunamis, earthquakes, landslides, volcanic activities, and heat and cold waves. In the last few years, several catastrophic events have occurred around the globe, causing many victims [17,102,103]. Dwellings should provide a secure shelter from these threats and not cause further harm. Intense land use, climate changes, urbanization, poor building quality, and the spread of informal settlements have increased the frequency and intensity of these tragedies $[104,105]$. These events can generate a deterioration of indoor environmental quality even when buildings resist the impact, worsening previously poor living conditions, as may happen in the case of shacks, basements, semi-basements, and garrets [104-107].

\section{Accessibility}

The aging population faces increasing morbidity, multi-morbidity, functional limitations, and disability $[108,109]$. Although aging is not a disease per se, the elderly are more fragile and susceptible to the harmful effects of their dwellings; therefore healthy ageing is a goal for an economically and socially sustainable future [17,110-115]. Of course, not only the elderly have movement limitations that need dwelling adaptation; such adaptation is also needed for many temporary, chronic, and acute conditions, among which are injuries from road, home, or work accidents, and genetic, neurodegenerative, autoimmune, cardiovascular, and infectious diseases [116,117]. The chance of living a healthy life for old and disabled people is linked to the possibility of using suitable indoor and outdoor spaces, especially at home, to conduct an independent and possibly active life [118-120]. To ensure these possibilities, living spaces ought to be designed for people with functional limitations, guaranteeing at least the activities of daily living (ADLs): bathing, dressing, ambulation, toileting, and feeding [119-121]. Accessibility for disabled people and safety for fragile people should be merged in new adapted/adaptable housing design.

\section{Neighborhoods and Area Characteristics}

As is already widely expressed in international literature, the concept of healthy housing also implies a residential setting that can fulfill the expectations of its residents [71,122]. In fact, the area characteristics include a broad set of aspects of both the physical and social environment, which exerts a powerful influence on health opportunities for the population [123-131]. For example, an urban morphology with high density seems to facilitate healthier choices, at least in terms of attitude towards physical activity, than urban forms characterized by scattered settlements and low residential density [132]. The presence of land-use mix, frequent road intersections between residential and commercial areas, etc., increase walkability, thereby facilitating direct pedestrian paths between various destinations [132]. At the same time, density can increase pollution, if neighborhoods are not well designed or managed. Air quality, noise, water supply, municipal waste management, transportation, and green areas represent features of the built environment that directly and indirectly impact citizens' health [71,122]. If the availability of environmental and social services differs among neighborhoods, the population's opportunities (including those for health) change, determining strong inequalities across and within cities $[133,134]$. For example, in peripheral areas, where low-income communities generally live, it is easier to find urban voids, abandoned buildings, and degraded lots, all conditions related to segregation and to an increased risk of violent behaviors [134]. Fear of crime is one of the most significant social problems in cities, negatively influencing people's lifestyle and mental health $[38,135-138]$. These problems are mainly observed in badly maintained housing estates with large housing blocks, which are poorly lit and receive little maintenance, along with large public open spaces with unclear management responsibilities [71,122]. 


\section{Perspectives}

As housing is a leading health determinant, improving living conditions in both economically developed and developing countries may reduce mortality and burden of disease, and increase health quality from a physical, psychological, and social point of view $[3,5,6,17,49,50,139]$. This goal can be easily combined with other socioeconomic challenges, such as poverty reduction, mitigation of climate changes, soil protection, and improving social cohesion, in accordance with several sustainable development goals (SDGs) of the United Nations Foundation 2030 Agenda (such as number 3, 6, 10, 11, 13, and 15) $[17,140]$. So far, we have briefly summarized some priorities in the field of housing and health; to achieve things at the local, national, and international levels, our proposals to be implemented are:

- $\quad$ Research, to consolidate evidence on the main health threats in indoor environments and to create strategies to mitigate their effects, as well as elaborating on guidelines and standards;

- Education, to spread research-acquired knowledge not only to health sector workers, but to engineers and architects, lawmakers, public administrators, and the general population (directly or via relevant stakeholders);

- Lawmaking, to enforce research-based regulation, as it is recognized as key part of health protection in built environments [9,46,69,141-143];

- $\quad$ Policy, to provide political and financial support to housing in local, national and international programs;

- Evaluation and control, to obtain a constant monitoring of implemented housing campaigns in input, output, and process validated indicators, and control of local health authorities on hygienic standards application.

To successfully implement these proposals, which we may call RELPE actions, strong commitment and functional coordination and harmonization is needed at a local, regional, national, and international level, providing the involvement of researchers, educators, public health operators, building designers, urban planners, lawmakers, communities, and representative associations.

\section{Conclusions}

Housing is a key determinant for human health. We have tried to summarize some of the major factors connecting housing and health, citing the most relevant scientific evidence currently available, that shows a strong relation with social and economic conditions; however, it is often very difficult to assess their independent effect [144]. The COVID-19 pandemic has strongly highlighted housing issues worldwide, especially for the lower socioeconomic part of different societies [41]. "Housing and health" as a subject should be approached with a multidisciplinary and transdisciplinary strategy in both research and practice [145-147] because of the complexity and wideness of its related aspects. In the last years, several studies have demonstrated the large potential for better human health through improvement of the living environment $[58,148,149]$. These results offer useful indications for the development of good practices to ameliorate built environment characteristics and make them available for all involved actors [17,71]. At the same time, a clear and updated regulatory system is a critical key factor to ensuring public health protection, relying on the most recent acquisitions of international scientific literature $[9,14,47,70,150]$. Innovative strategies that can match together different aspects (technical building, urban, social, legal, political), such as the RELPE that we have modestly suggested, should be elaborated, discussed, experimented, evaluated, and implemented, to achieve things on the local, national and international levels, in order to achieve the desired results in terms of public health.

Author Contributions: L.C. and D.D. equally contributed to the paper. All authors have read and agreed to the published version of the manuscript. 
Funding: This research received no external funding.

Institutional Review Board Statement: Not applicable.

Informed Consent Statement: Not applicable.

Conflicts of Interest: The authors declare no conflict of interest.

\section{References}

1. Shaw, M. Housing and Public Health. Annu. Rev Public Health 2004, 25, 397-418. [CrossRef] [PubMed]

2. D'Alessandro, D.; Appolloni, L.; Capasso, L. Public health and urban planning: A powerful alliance to be enhanced in Italy. Ann. Ig. 2017, 29, 453-463. [CrossRef]

3. Whitehead, M.; Dahlgren, G. What can be done about inequalities in health? Lancet 1991, 338, 1059-1063. [CrossRef]

4. Krieger, J.; Higgins, D.L. Housing and Health: Time Again for Public Health Action. Am. J. Public Health 2002, 92, 758-768. [CrossRef] [PubMed]

5. Lowry, S. An introduction to housing and health. BMJ 1989, 299, 1261-1262. [CrossRef]

6. Goromosov, M.S. Bases Physiologiques des Normes D'hygiene Applicables au Logement; OMS: Geneve, Switzerland, 1968.

7. Jacobs, D.E.; Kelly, T.; Sobolewski, J. Linking Public Health, Housing, and Indoor Environmental Policy: Successes and Challenges at Local and Federal Agencies in the United States. Environ. Health Perspect. 2007, 115, 976-982. [CrossRef]

8. Martin, W.J.; Glass, R.I.; Balbus, J.M.; Collins, F.S. A major environmental cause of death. Science 2011, 334, 180-181. [CrossRef]

9. Capasso, L.; Gaeta, M.; Appolloni, L. Health inequalities and inadequate housing: The case of exceptions to hygienic requirements for dwellings in Italy. Ann. Ig. 2017, 29, 323-331.

10. De Martino, A. Linee-guida per la tutela e la promozione della salute negli ambienti confinati. Ig. Sanita Pubbl. 2001, 57, 407-414.

11. Brasche, S.; Bischof, W. Daily time spent indoors in German homes-Baseline data for the assessment of indoor exposure of German occupants. Int. J. Hyg. Environ. Health 2005, 208, 247-253. [CrossRef]

12. Bruce, N.; Perez-Padilla, R.; Albalak, R. Indoor air pollution in developing countries: A major environmental and public health challenge. Bull. World Health Organ. 2000, 78, 1078-1092. [PubMed]

13. Hood, E. Dwelling disparities: How poor housing leads to poor health. Env. Health Perspect 2005, 113, A310-A317. [CrossRef]

14. Braubach, M.; Heroux, M.E.; Korol, N.; Paunovic, E.; Zastenskaya, I.A. The value of housing conditions and urban environment for the health. Hyg. Sanit. 2014, 1, 9-15.

15. Housing and COVID-19. Available online: https://unhabitat.org/sites/default/files/2020/05/130520_-_housing_and_covid-19 _key_messages.pdf (accessed on 14 July 2021).

16. Mehdipanah, R. Housing as a Determinant of COVID-19 Inequities. Am. J. Public Health 2020, 110, 1369-1370. [CrossRef]

17. World Health Organization (WHO). Housing and Health Guidelines; World Health Organization: Geneve, Switzerland, 2019.

18. Jacobs, D.E. Environmental Health Disparities in Housing. Am. J. Public Health 2011, 101 (Suppl. 1), S115-S122. [CrossRef] [PubMed]

19. Adequate Housing and Slum Upgrading. Available online: https://unhabitat.org/sites/default/files/2020/06/indicator_11.1.1 _training_module_adequate_housing_and_slum_upgrading.pdf (accessed on 14 July 2021).

20. Belyaev, I.; Dean, A.; Egor, H.; Hubmann, G.; Jandrisovits, R.; Kern, M.; Kundi, M.; Moshammer, H.; Lercher, P.; Müller, K.; et al. EUROPAEM EMF Guidelines 2016 for the prevention, diagnosis and treat-ment of EMF-related health problems and illnesses. Rev. Env. Health 2016, 31, 363-397. [CrossRef]

21. Bortkiewicz, A. Health effects of radiofrequency electromagnetic fields (RD EMF). Ind. Health 2019, 57, 403-405. [CrossRef]

22. European Commission. Non-Binding Guide to Good Practive for Implementing Directive 2013/35/EU Electomagnetic Fields; EaSI Programme 2014-2020 European Union, 2015; Publication Office of The EU: Luxembourg, Luxembourg, 2015; Volume 1, Practical Guide.

23. WHO. Electromagnetic Fields and Public Health. Intermediate Frequencies (IF). WHO 2005. Available online: https://www.who. int/peh-emf/publications / facts/intermediatefrequencies_infosheet.pdf?ua=1 (accessed on 7 October 2021).

24. IARC Working Group on the Evaluation of Carcinogenic Risks to Humans. In Non-Ionizing Radiation, Part 1: Static and Extremely Low-Frequency (ELF) Electric and Magnetic Fields; Monographs on the Evaluation of Carcinogenic Risks to Humans; IARC: Lyon, France, 2002; Volume 80.

25. Baan, R.; Grosse, Y.; Lauby-Secretan, B.; El Ghissassi, F.; Bouvard, V.; Benbrahim-Tallaa, L.; Guha, N.; Islami, F.; Galichet, L.; Straif, K. Carcinogenicity of radiofrequency electromagnetic fields. Lancet Oncol. 2011, 12, 624-626. [CrossRef]

26. Pecoraro, F.; Luzi, D.; Pourabbas, E.; Ricci, F.L. A system of concepts to support the integration of Health and social care and assistive domotics services: The Health@Home project. Inform. Health Soc. Care 2021, 46, 333-344. [CrossRef]

27. Van Hoof, J.; Kort, H.S.M.; Rutten, P.G.S.; Duijnstee, M.S.H. Ageing-in-place with the use of ambient intelligence technology: Perspectives of older users. Int. J. Med. Inform. 2011, 80, 310-331. [CrossRef]

28. Oetzel, M.; Spiekermann, S. A systematic methodology for privacy impact assessments-A design science approach. Eur. J. Inf. Syst. 2013, 23, 126-150. [CrossRef]

29. Cavoukian, A.; Fisher, A.; Killen, S.; Hoffman, D.A. Remote home health care technologies: How to ensure privacy? Identity Inf. Soc. 2010, 3, 363-378. [CrossRef]

30. Aboujaoude, E. Protecting privacy to protect mental health: The new ethical imperative. J. Med. Ethics 2019, 45, 604-607. [CrossRef] [PubMed] 
31. Lowry, S. Health and housing: Noise, space, and light. Br. Med. J. 1989, 299, 1439-1442. [CrossRef]

32. WHO Europe. Large Analysis and Review of European Housing and Health Status (LARES); WHO Regional Office for Europe: Copenhagen, Denmark, 2007.

33. Appolloni, L.; D'Alessandro, D. Housing Spaces in Nine European Countries: A Comparison of Dimensional Requirements. Int. J. Environ. Res. Public Health 2021, 18, 4278. [CrossRef]

34. Ishak, N.H.; Ariffin, A.R.M.; Sulaiman, R.; Zailani, M.N.M. Rethinking space design standards toward quality affordable housing in Malaysia. In MATEC Web of Conferences; EDP Sciences: Les Ulis, France, 2016; Volume 66, p. 112.

35. McNicholas, A.; Lennon, D.; Crampton, P.; Howden-Chapman, P. Overcrowding and infectious diseases-When will we learn the lessons of our past? N. Z. Med. J. 2000, 113, 453-454.

36. Stein, L. A Study of Respiratory Tuberculosis in Relation to Housing Conditions in Edinburgh: I.-The Pre-War Period. Br. J. Soc. Med. 1950, 4, 143-169. [CrossRef]

37. Dietz, L.; Horve, P.F.; Coil, D.A.; Fretz, M.; Eisen, J.A.; Van Den Wymelenberg, K. Novel Coronavirus (COVID-19) pandemic: Built environment considerations to reduce transmission. mSystems 2020, 5, e0245-20. [PubMed]

38. Evans, G.W. The built environment and mental health. J. Urban. Health 2003, 80, 536-555. [CrossRef] [PubMed]

39. Riley, R.L.; Wells, W.F.; Mills, C.C.; Nyka, W.; Mclean, R.L. Air hygiene in tuberculosis: Quantitative studies of infectivity and control in a pilot ward. Am. Rev. Tuberc. 1957, 75, 420-431.

40. Humphries, C. Indoor Ecosystems. Science 2012, 335, 648-650. [CrossRef] [PubMed]

41. Li, Y.; Nazaroff, W.W.; Bahnfleth, W.; Wargocki, P.; Zhang, Y. The COVID-19 pandemic is a global indoor air crisis that should lead to change: A message commemorating 30 years of Indoor Air. Indoor Air 2021, 31, 1683-1686. [CrossRef]

42. Chambers, E.C.; Fuster, D.; Suglia, S.F.; Rosenbaum, E. Depressive symptomology and hostile affect among Latinos using housing rental assistance: The AHOME study. J. Urban. Health 2015, 92, 611-621. [CrossRef] [PubMed]

43. Amerio, A.; Brambilla, A.; Morganti, A.; Aguglia, A.; Bianchi, D.; Santi, F.; Costantini, L.; Odone, A.; Costanza, A.; Signorelli, C.; et al. COVID-19 Lockdown: Housing Built Environment's Effects on Mental Health. Int. J. Environ. Res. Public Health 2020, 17, 5973. [CrossRef] [PubMed]

44. Hanson, J. Decoding Homes and Houses; Cambridge University Press (CUP): Cambridge, UK, 1999.

45. Reshetnikov, V.; Mitrokhin, O.; Belova, E.; Mikhailovsky, V.; Mikerova, M.; Alsaegh, A.; Yakushina, I.; Royuk, V. Indoor Environmental Quality in Dwellings and Lifestyle Behaviors during the COVID-19 Pandemic: Russian Perspective. Int. J. Environ. Res. Public Health 2021, 18, 5975. [CrossRef]

46. Popov, V.I.; D'Alessandro, D.; Gaeta, M.; Capasso, L. Lighting requirements of dwellings: A comparison between Russian federation and Italy. Ann. Ig. 2016, 28, 202-207. [PubMed]

47. Braubach, M. Key challenges of housing and health from WHO perspective. Int. J. Public Health 2011, 56, 579-580. [CrossRef]

48. Lowry, S. Housing and health: Indoor air quality. BMJ 1989, 299, 1388-1390. [CrossRef]

49. Bonnefoy, X.R.; Braubach, M.; Moissonnier, B.; Monolbaev, K.; Röbbel, N. Housing and Health in Europe: Preliminary Results of a Pan-European Study. Am. J. Public Health 2003, 93, 1559-1563. [CrossRef]

50. Gubernskiı̌, D.; Rakhmanin, A.; Leshchikov, V.A. The human residential ecology: Problems and future prospects. Vestn. Ross. Akad. Meditsinskikh Nauk 2003, 3, 9-13.

51. Capasso, L.; Schioppa, F.S. 150 anni di requisti igieinico sanitari delle abitazioni in Italia. Ann. Ig. 2012, 24, $207-216$.

52. Sundell, J. On the history of indoor air quality and health. Indoor Air 2004, 14 (Suppl. 7), 51-58. [CrossRef]

53. Cassedy, J.H. George Rosen. In A History of Public Health; The Johns Hopkins University Press: Baltimore, MD, USA, 1993.

54. Clarisse, B.; Seta, N.; El Hasnaoui, A.; Terrioux, P.; Momas, I. How to describe indoor environment in epidemiological studies dealing with respiratory diseases. Rev. D'épidémiol. St. Publique 2002, 50, 179-200.

55. Wimalasena, N.; Chang-Richards, A.; Wang, K.; Dirks, K. Housing Risk Factors Associated with Respiratory Disease: A Systematic Review. Int. J. Environ. Res. Public Health 2021, 18, 2815. [CrossRef] [PubMed]

56. Amegah, A.K.; Jaakkola, J. Household air pollution and the sustainable development goals. Bull. World Health Organ. 2016, 94, 215-221. [CrossRef] [PubMed]

57. Mendell, M.J.; Mirer, A.G.; Cheung, K.; Tong, M.; Douwes, J. Respiratory and Allergic Health Effects of Dampness, Mold, and Dampness-Related Agents: A Review of the Epidemiologic Evidence. Environ. Health Perspect. 2011, 119, 748-756. [CrossRef]

58. Thomson, H.; Petticrew, M.; Morrison, D. Health effects of housing improvement: Systematic review of intervention studies. BMJ 2001, 323, 187-190. [CrossRef]

59. Jaakkola, J.J.K.; Hwang, B.-F.; Jaakkola, M.S. Home Dampness and Molds as Determinants of Allergic Rhinitis in Childhood: A 6-Year, Population-based Cohort Study. Am. J. Epidemiol. 2010, 172, 451-459. [CrossRef]

60. Conti, O.G.; Ledda, C.; Fiore, M.; Mauceri, C.; Sciacca, S.; Ferrante, M.L. Allergic rhinitis and asthma in children and indoor pollution. Ig. Sanita Pubblica 2011, 67, 467-480.

61. Couch, R.B. Viruses and indoor air pollution. Bull. N. Y. Acad. Med. 1981, 57, 907-921.

62. Chen, J.-K.; Wu, C.; Su, T.-C. Positive Association between Indoor Gaseous Air Pollution and Obesity: An Observational Study in 60 Households. Int. J. Environ. Res. Public Health 2021, 18, 11447. [CrossRef] [PubMed]

63. Seppänen, O.A.; Fisk, W.J. Summary of human responses to ventilation. Indoor Air 2004, 14 (Suppl. 7), 102-118. [CrossRef] [PubMed]

64. Liddament, M.W. A Review of Ventilation and the Quality of Ventilation Air. Indoor Air 2000, 10, 193-199. [CrossRef]

65. Fanger, P.O. What is IAQ? Indoor Air 2006, 16, 328-334. [CrossRef] [PubMed] 
66. IARC. Agents Classified by the IARC Monographs; IARC: Lyon, France, 2021; Volumes 1-123.

67. Bissett, R.J.; McLaughlin, J.R. Radon. Chronic Dis. Can. 2010, 29 (Suppl. 1), 38-50. [CrossRef]

68. Sundell, J.; Levin, H.; Nazaroff, W.; Cain, W.S.; Fisk, W.J.; Grimsrud, D.T.; Gyntelberg, F.; Li, Y.; Persily, A.K.; Pickering, A.C.; et al. Ventilation rates and health: Multidisciplinary review of the scientific literature. Indoor Air 2011, 21, 191-204. [CrossRef]

69. Li, Y. Hypothesis: SARS-CoV-2 transmission is predominated by the short-range airborne route and exacerbated by poor ventilation. Indoor Air 2021, 31, 921-925. [CrossRef] [PubMed]

70. Morawska, L.; Allen, J.; Bahnfleth, W.; Bluyssen, P.M.; Boerstra, A.; Buonanno, G.; Cao, J.; Dancer, S.J.; Floto, A.; Franchimon, F.; et al. A paradigm shift to combat indoor respiratory infection. Science 2021, 372, 689-691. [CrossRef]

71. Bonnefoy, X. Inadequate housing and health: An overview. Int. J. Environ. Pollut. 2007, 30, 411. [CrossRef]

72. Elinson, L. Health Policy and Epidemiology: The Scientific Evidence for a Ban of Urea-Formaldehyde Foam Insulation. J. Public Health Policy 1984, 5, 513. [CrossRef]

73. Main, D.M.; Hogan, T.J. Health Effects of Low-Level Exposure to Formaldehyde. J. Occup. Environ. Med. 1983, 25, 896-900. [CrossRef]

74. United States Environmental Protection Agency. Volatile Organic Compounds Impact on Indoor Air Quality. 2017. Available online: https: / / www.epa.gov/indoor-air-quality-iaq/volatile-organic-compounds-impact-indoor-air-quality (accessed on 7 July 2021).

75. Kuehn, B.M. Stronger Formaldehyde Regulation Sought. JAMA 2008, 299, 2015. [CrossRef] [PubMed]

76. Oliver, L.C.; Shackleton, B.W. The indoor air we breathe. Public Health Rep. 1998, 113, 398-409. [PubMed]

77. Redlich, C.A.; Sparer, J.; Cullen, M.R. Sick-building syndrome. Lancet 1997, 349, 1013-1016. [CrossRef]

78. Ezratty, V. The sick building syndrome (SBS). Presse Med. 2003, 32, 1572-1579.

79. Seltzer, J.M. Building-related illnesses. J. Allergy Clin. Immunol. 1994, 94 Pt 2, 351-361. [CrossRef]

80. Miller, C.S. Chemical sensitivity: Symptom, syndrome or mechanism for disease? Toxicology 1996, 111, 69-86. [CrossRef]

81. Win-Shwe, T.T.; Fujimaki, H.; Arashidani, K.; Kunugita, N. Indoor volatile organic compounds and chemical sensitivity reactions. Clin. Dev. Immunol. 2013, 2013, 623812. [CrossRef]

82. Hemsath, T.L.; Walburn, A.; Jameton, A.; Gulsvig, M. A review of possible health concerns associated with zero net energy homes. Neth. J. Hous. Environ. Res. 2012, 27, 389-400. [CrossRef]

83. Wallner, P.; Tappler, P.; Munoz, U.; Damberger, B.; Wanka, A.; Kundi, M.; Hutter, H.-P. Health and Wellbeing of Occupants in Highly Energy Efficient Buildings: A Field Study. Int. J. Environ. Res. Public Health 2017, 14, 314. [CrossRef]

84. Leech, J.A.; Raizenne, M.; Gusdorf, J. Health in occupants of energy efficient new homes. Indoor Air 2004, 14, 169-173. [CrossRef] [PubMed]

85. Balmes, J.R. Household air pollution from domestic combustion of solid fuels and health. J. Allergy Clin. Immunol. 2019, 143, 1979-1987. [CrossRef]

86. Smith, K.R. Indoor air pollution in developing countries: Recommendations for researcht. Indoor Air 2002, 12, 198-207. [CrossRef]

87. Neghab, M.; Fard, A.R.; Habibi, M.; Choobineh, A. Home accidents in rural and urban areas of Shiraz, 2000-02. East. Mediterr. Health J. 2006, 12, 824-833.

88. Gielen, A.C.; McDonald, E.M.; Shields, W. Unintentional Home Injuries Across the Life Span: Problems and Solutions. Annu. Rev. Public Health 2015, 36, 231-253. [CrossRef]

89. Runyan, C.W.; Casteel, C.; Perkis, D.; Black, C.; Marshall, S.W.; Johnson, R.M.; Coyne-Beasley, T.; Waller, A.E.; Viswanathan, S. Unintentional injuries in the home in the United States Part I: Mortality. Am. J. Prev. Med. 2005, 28, 73-79. [CrossRef] [PubMed]

90. Runyan, C.W.; Perkis, D.; Marshall, S.W.; Johnson, R.M.; Coyne-Beasley, T.; Waller, A.E.; Black, C.; Baccaglini, L. Unintentional injuries in the home in the United States: Part II: Morbidity. Am. J. Prev. Med. 2005, 28, 80-87. [CrossRef] [PubMed]

91. Mack, K.A.; Rudd, R.A.; Mickalide, A.D.; Ballesteros, M.F. Fatal Unintentional Injuries in the Home in the U.S., 2000-2008. Am. J. Prev. Med. 2013, 44, 239-246. [CrossRef]

92. McDonald, E.M.; Mack, K.; Shields, W.C.; Lee, R.P.; Gielen, A.C. Primary Care Opportunities to Prevent Unintentional Home Injuries: A Focus on Children and Older Adults. Am. J. Lifestyle Med. 2018, 12, 96-106. [CrossRef] [PubMed]

93. Lowry, S. Housing and health: Accidents at home. BMJ 1990, 300, 104-106. [CrossRef]

94. Child Death by Injury in Rich Nations. Available online: https://www.unicef-irc.org/publications/pdf/repcard2e.pdf (accessed on 15 July 2021).

95. Falls. Available online: https://www.who.int/news-room/fact-sheets/detail/falls (accessed on 15 July 2021).

96. EuroSafe. Injuries in the European Union, Summary on Injury Statistics for the Years 2012-2014, 6th ed.; EuroSafe: Amsterdam, The Netherlands, 2016.

97. Jacobsen, L.A.; Kent, M.; Lee, M.; Mather, M. America's Aging Population. Popul. Bullettin. 2011, 66, 2-16.

98. Keall, M.D.; Pierse, N.; Howden-Chapman, P.; Cunningham, C.; Cunningham, M.; Guria, J.; Baker, M.G. Home modifications to reduce injuries from falls in the home injury prevention intervention (HIPI) study: A cluster-randomised controlled trial. Lancet 2015, 385, 231-238. [CrossRef]

99. Falls among Older Adults in the EU-28. Available online: https://eupha.org/repository/sections/ipsp/Factsheet_falls_in_ older_adults_in_EU.pdf (accessed on 16 July 2021).

100. Saegert, S.C.; Klitzman, S.; Freudenberg, N.; Cooperman-Mroczek, J.; Nassar, S. Healthy Housing: A Structured Review of Published Evaluations of US Interventions to Improve Health by Modifying Housing in the United States, 1990-2001. Am. J. Public Health 2003, 93, 1471-1477. [CrossRef] [PubMed] 
101. Gielen, A.C.; Bachman, G.; Badaki-Makun, O.; Johnson, R.M.; McDonald, E.; Omaki, E.; Porter, K.M.P.; Ryan, L.; Shields, W. National survey of home injuries during the time of COVID-19: Who is at risk? Inj. Epidemiol. 2020, 7, 63. [CrossRef]

102. UNISDR (United Nations International Strategy for Disaster Reduction). Sendai Framework for Disaster Risk Reduction 2015-2030; UNISDR: Geneva, Switzerland, 2015.

103. Green, H.K.; Lysaght, O.; Saulnier, D.D.; Blanchard, K.; Humphrey, A.; Fakhruddin, B.; Murray, V. Challenges with Disaster Mortality Data and Measuring Progress Towards the Implementation of the Sendai Framework. Int. J. Disaster Risk Sci. 2019, 10, 449-461. [CrossRef]

104. World Health Organization (WHO). Climate Change and Human Health, Risks and Responses; World Health Organization: Geneva, Switzerland, 2003.

105. Han, H.-J.; Kim, J.-H.; Chung, S.-E.; Park, J.-H.; Cheong, H.-K. Estimation of the National Burden of Disease and Vulnerable Population Associated with Natural Disasters in Korea: Heavy Precipitation and Typhoon. J. Korean Med. Sci. 2018, 33 , e314. [CrossRef] [PubMed]

106. Azuma, K.; Ikeda, K.; Kagi, N.; Yanagi, U.; Hasegawa, K.; Osawa, H. Effects of water-damaged homes after flooding: Health status of the residents and the environmental risk factors. Int. J. Environ. Health Res. 2014, 24, 158-175. [CrossRef]

107. Capasso, L.; Basti, A.; Savino, A.; Flacco, M.E.; Manzoli, L.; D'Alessandro, D. Semi-basements used as dwellings: Hygienic considerations and analysis of the regulations. Ann. Ig. 2014, 26, 3-9.

108. Granbom, M.; Iwarsson, S.; Kylberg, M.; Pettersson, C.; Slaug, B. A public health perspective to environmental barriers and accessibility problems for senior citizens living in ordinary housing. BMC Public Health 2016, 16, 772. [CrossRef]

109. Prince, M.J.; Wu, F.; Guo, Y.; Robledo, L.M.G.; O’Donnell, M.; Sullivan, R.; Yusuf, S. The burden of disease in older people and implications for health policy and practice. Lancet 2015, 385, 549-562. [CrossRef]

110. Beard, J.; Bloom, D. Towards a comprehensive public health response to population ageing. Lancet 2015, 385, 658-661. [CrossRef]

111. Lloyd-Sherlock, P.; McKee, M.; Ebrahim, S.; Gorman, M.; Greengross, S.; Prince, M.; Pruchno, R.; Gutman, G.; Kirkwood, T.; O'Neill, D.; et al. Population ageing and health. Lancet 2012, 379, 1295-1296. [CrossRef]

112. Healthy Ageing and Functional Ability. Available online: https://www.who.int/westernpacific/news/q-a-detail/ageinghealthy-ageing-and-functional-ability (accessed on 17 July 2021).

113. Lowry, S. Housing and health: Housing for people with special needs. BMJ 1990, 300, 321-323. [CrossRef] [PubMed]

114. Manton, K.G. Recent Declines in Chronic Disability in the Elderly U.S. Population: Risk Factors and Future Dynamics. Annu. Rev. Public Health 2008, 29, 91-113. [CrossRef]

115. Kirkwood, T.B.L. A systematic look at an old problem. Nature 2008, 451, 644-647. [CrossRef]

116. World Health Organization (WHO). International Classification of Functioning, Disability and Health: ICF; WHO Publishing: Geneva, Switzerland, 2001.

117. Centers for Disease Control and Prevention (CDC). Prevalence of disabilities and associated health conditions among adultsUnited States, 1999. Morb. Mortal. Wkly. Rep. 2001, 50, 120-125.

118. Helle, T.; Brandt, A.; Slaug, B.; Iwarsson, S. Lack of research-based standards for accessible housing: Problematization and exemplification of consequences. Int. J. Public Health 2011, 56, 635-644. [CrossRef]

119. Crews, D.E. Artificial environments and an aging population: Designing for age-related functional losses. J. Physiol. Anthr. Appl. Hum. Sci. 2005, 24, 103-109. [CrossRef]

120. Katz, S.; Ford, A.B.; Moskowitz, R.W.; Jackson, B.A.; Jaffe, M.W. Studies of illness in the aged. the index of ADL: A standardized measure of biological and psychosocial function. JAMA 1963, 185, 914-919. [CrossRef]

121. Crews, D.E.; Zavotka, S. Aging, Disability, and Frailty: Implications for Universal Design. J. Physiol. Anthr. 2006, 25, 113-118. [CrossRef]

122. Capolongo, S.; Rebecchi, A.; Dettori, M.; Appolloni, L.; Azara, A.; Buffoli, M.; Capasso, L.; Casuccio, A.; Oliveri Conti, G.; D'Amico, A.; et al. Healthy design and urban planning strategies, action and policy to achieve salutogenic cities. Int. J. Environ. Res. Public Health 2018, 15, 2698. [CrossRef]

123. Freeman, L. America's Affordable Housing Crisis: A Contract Unfulfilled. Am. J. Public Health 2002, 92, 709-712. [CrossRef]

124. Galea, S.; Vlahov, D. URBAN HEALTH: Evidence, Challenges, and Directions. Annu. Rev. Public Health 2005, 26, 341-365. [CrossRef]

125. Ludwig, J.; Duncan, G.J.; Gennetian, L.A.; Katz, L.F.; Kessler, R.C.; Kling, J.R.; Sanbonmatsu, L. Neighborhood effects on the long-term well-being of low-income adults. Science 2012, 337, 1505-1510. [CrossRef]

126. Rydin, Y.; Bleahu, A.; Davies, M.; Dávila, J.D.; Friel, S.; De Grandis, G.; Groce, N.; Hallal, P.C.; Hamilton, I.; Howden-Chapman, P.; et al. Shaping cities for health: Complexity and the planning of urban environments in the 21st century. Lancet 2012, 379, 2079-2108. [CrossRef]

127. Dye, C. Health and Urban Living. Science 2008, 319, 766-769. [CrossRef] [PubMed]

128. Jackson, R.; Harp, T.; Wright, T. Land use planning: Why public health must be involved. J. Law Med. Ethic. 2002, 30 (Suppl. 3), 70-74.

129. Mackenbach, J.P.; Howden-Chapman, P. Houses, neighbourhoods and health. Eur. J. Public Health 2002, 12, 161-162. [CrossRef] [PubMed]

130. Fullilove, M.T. Root Shock: How Tearing up Cities Neighborhoods Hurts America and What We Can Do about It; Ballantine: New York, NY, USA, 2004. 
131. Mehdipanah, R.; Dewar, M.; Eisenberg, A. Threats to and Opportunities for Low-Income Homeownership, Housing Stability, and Health: Protocol for the Detroit 2017 Make-It-Home Evaluation Study. Int. J. Environ. Res. Public Health 2021, 18, 11230. [CrossRef] [PubMed]

132. Swinburn, B.A.; Sacks, G.; Hall, K.D.; McPherson, K.; Finegood, D.T.; Moodie, M.; Gortmaker, S.L. The global obesity pandemic: Shaped by global drivers and local environments. Lancet 2011, 378, 804-814. [CrossRef]

133. World Health Organization (WHO). Addressing the Social Determinants of Health: The Urban Dimension and the Role of Local Government. WHO, Geneve, 2012. Available online: https://www.euro.who.int/_data/assets/pdf_file/0005/166136/ UrbanDimensions.pdf?ua=1\&gathStatIcon=true (accessed on 7 October 2020).

134. World Health Organization (WHO). Environmental Health Inequalities in Europe. Assessment Report. WHO. 2012. ISBN 9789289002608. Available online: https:/ /www.euro.who.int/_data/assets/pdf_file/0010/157969/e96194.pdf (accessed on 7 October 2020).

135. Branas, C.C.; South, E.; Kondo, M.C.; Hohl, B.C.; Bourgois, P.; Wiebe, D.J.; MacDonald, J.M. Citywide cluster randomized trial to restore blighted vacant land and its effects on violence, crime, and fear. Proc. Natl. Acad. Sci. USA 2018, 115, 2946-2951. [CrossRef] [PubMed]

136. Valera, S.; Guàrdia, J. Perceived insecurity and fear of crime in a city with low-crime rates. J. Environ. Psychol. 2014, 38, 195-205. [CrossRef]

137. Okkels, N.; Kristiansen, C.B.; Munk-Jørgensen, P.; Sartorius, N. Urban mental health: Challenges and perspectives. Curr. Opin. Psychiatry 2018, 31, 258-264. [CrossRef]

138. Gruebner, O.; Rapp, M.A.; Adli, M.; Kluge, U.; Galea, S.; Heinz, A. Cities and Mental Health. Dtsch. Aerzteblatt Online 2017, 114, 121-127. [CrossRef]

139. Leyden, K.M. Social Capital and the Built Environment: The Importance of Walkable Neighborhoods. Am. J. Public Health 2003, 93, 1546-1551. [CrossRef]

140. Sustainable Development Goals. Available online: https://unfoundation.org/what-we-do/issues/sustainable-developmentgoals / (accessed on 17 July 2021).

141. Perdue, W.C.; Stone, L.A.; Gostin, L.O. The Built Environment and Its Relationship to the Public's Health: The Legal Framework. Am. J. Public Health 2003, 93, 1390-1394. [CrossRef]

142. Chauvin, J.; Pauls, J.; Strobl, L.; Chauvin, J.P.J. Building codes: An often overlooked determinant of health. J. Public Health Policy 2016, 37, 136-148. [CrossRef]

143. Gubernskiǔ, D.; Kalinina, N.V. Sociohygienic monitoring of residential space. Gig. Sanit. 2004, 5, 15-16.

144. Ranson, R. Healthy Housing: A Practical Guide; E\&FN SPON e WHO Europe: London, UK, 2005.

145. Lawrence, R. Constancy and Change: Key Issues in Housing and Health Research, 1987-2017. Int. J. Environ. Res. Public Health 2017, 14, 763. [CrossRef] [PubMed]

146. Lawrence, R.J. Housing and Health: Beyond Disciplinary Confinement. J. Hered. 2006, 83, 540-549. [CrossRef] [PubMed]

147. Lawrence, R.J. Housing and health: From interdisciplinary principles to transdisciplinary research and practice. Futures 2004, 36, 487-502. [CrossRef]

148. Taylor, L.A. Housing And health: An overview of the literature. Health Aff. Health Policy Brief 2018, 7, 10.

149. Thomson, H.; Thomas, S.; Sellstrom, E.; Petticrew, M. Housing improvements for health and associated socio-economic out-comes. Cochrane Database Syst. Rev. 2013, 28, CD008657.

150. Signorelli, C.; Odone, A.; Buffoli, M.; Capolongo, S. Building codes and public health on both sides of the Atlantic. J. Public Health Policy 2016, 37, 385-387. [CrossRef] [PubMed] 